\title{
INTERPERSONAL COMMUNICATION ROLE FOR SELF- CONCEPT OF CHILDREN AND FAMILIES
}

\author{
Muhammad Thariq \\ Muhammadiyah University of North Sumatera(UMSU), Medan, Indonesia \\ muhammadthariq@umsu.ac.id
}

\begin{abstract}
This study intends to know "How can interpersonal communication build family resilience in the face of increasingly tough challenges"? To reveal the reality of the authors use qualitative methods. To get the data, the author uses three techniques of data collection that is observation, in-depth interview and documentation study. The results of this study found that interpersonal communication plays an important role in shaping family resilience and strengthen the functioning of families facing increasingly severe challenges. Interpersonal communication between parent and child through the giving of statements such as "Know your family and remember who you are", "we live not alone" and "remember neighbors, remember family" can form self concept or character of child and family in society as do parents to the children / family in Neighborhood 1 Pasar 6 Kelurahan Tanjungsari Kecamatan Medan Selayang, Medan City, North Sumatera Province. There are positive family relationships and actions built on the basis of conversation, conformity, dependency and distribution of powers derived from parents and children as in families in Neighborhood I Pasar 6 Tanjungsari Village, Kec. Medan Selayang, so as to build a warm and supportive relationship that is characterized by mutual respect and care for each other. With the capital of interpersonal communication, the family can function in building relationships between families and social relations in the form of arisan aged 20 years more. Finally, the family communication (old family) upholds family secrets and restrictions on taboo matters.
\end{abstract}

Keywords: social relations; interpersonal communication; conversation; conformity 


\section{INTRODUCTION}

The family is the main pillar of life, especially for young generation. The family is the first educator and guard leader to realize human resources. For that the total support of the family is able to give birth as if a miracle in their life. Such is the urgency of the function of the family as the smallest organization in the structure of society that contributes to the character and the mental state. Thus a strong nation depends on building a good family so that the family can become a pillar of development. But the hope of a formidable family to shape the nation's character and mentality is not always directly proportional to the reality in today's society. This is in line with family pressure even more severe because of the growing economic demands, technological developments to the increasingly heavy social changes as well. As a result the function of families in the community declined in the face of the nation's problems. Slowly but surely the weakness of family function has an impact on family resilience in shaping the character and mental of the nation. These family classic problems mentioned above, such as economy, education, and low access to healthy boards are still facing many Indonesian families. Unfinished, the family is already faced with more complicated new challenges .The development of internet, consumerism, fading of appreciation, respect and caring to others until the problem of narcotics circulation, dishonesty, corruption and radicalism increasingly undermined the function of the family. Not to mention on the other hand, globalization, increasing individualism and increasingly weak social control make the burden faced greater.

Chairman of Center for Child and Family Welfare Studies Padjadjaran University Bandung Nunung Nurwati (Kompas: 2017) said, only with the strength of family resilience, the various problems that can be passed. Weak family role will only give birth to a generation of weak and troubled nation. Still in Compass, according to Nunung Nurwati, whatever happened to the nation all started from the family. Although the family plays an important role in determining the civilization of the nation, until now the family's development is still marginalized. Data from compass 2017, Indonesia has more than 65 million families. The new family development 
program is focused on economic empowerment. Along with the government's economic empowerment program, parents or families need to gain an understanding of the importance of the role of interpersonal communication in the family. The re-affirmation of the importance of interpersonal communication in the family is considered to anticipate the impact of internet exposure and communication technology slowly but surely has changed the pattern of family communication and eroded family resilience. Direct face-to-face communication as a feature of interpersonal communication allows each party to read facial expressions, body language, to allow for a comfortable caress or touch between parent and child will shape the reality of family togetherness. That atmosphere can in turn affect warm and supportive family relationships and actions that are characterized by mutual respect and mutual care. Such family behavior can shape a positive child's character as well. To the authors review and examine the power of interpersonal communication in the community in Pasar 6 Environment I Kelurahan Tanjungsari District Medan Selayang, Medan City, which first saw face-to-face communication in the family conducted by parents to hereditary done to children and grandchildren which indirectly fostered a family arisan for 20 years. Is not that reality as a family resilience capital amid changes in communication patterns that also weaken the resilience of family, character and mental nation today. The authors hope the results of this study into a basis of both theoretical and practical to build family resilience by strengthening family communication amid the development of internet and text-based voice and communication technology.

\section{METHODS OF THE RESEARCH}

In line with the purpose of the study, the author uses a qualitative-descriptive research method. Qualitative approach is useful to describe a reality, family condition, relationships and actions in society.

\subsection{Technique of Collection Data}

Data collection techniques in this study were conducted in three ways, namely (1) observation through participatory approaches, (2) in-depth interviews and (3) the use of 
documents. Observation through participatory approach to reveal the phenomenon in field researchers using observation techniques. The observed observations are the participant observations or engagements involved. The observation involved is that the observations made by the smabill are at least partly involved in the life studied. Observations are seen following the people who are researched in their daily lives, seeing what (Becker in Mulyana, 2001: 162) In this case the authors hold observations and participate in the community in Pasar 6 Neighborhood I Tanjungsari Urban Village, Medan Selayang Subdistrict, Medan City, and observe the reality of communication between parents and children as well as relations between families and interactions. Data collection techniques with open or in-depth interviews allow informants to give free views. This interview allows the researcher to ask deep questions. Therefore, to complement the data of this research, especially in an effort to obtain the data that is accurate about this research, researchers will conduct interviews with informants. In this research the interview to be used is Interview depth or unstructured interview. Unstructured interviews are similar to informal conversations that are flexible, questionnaires or words can be changed during interviews, tailored to the needs and conditions of the informants encountered (Mulyana, 2001: 181).

\subsection{Analysis Method}

As in qualitative research, data analysis of this research is done when data collection, even data analysis done since the beginning and throughout the research process took place. To draw conclusions of data collected processed through the process of reduction, data presentation and verification. (Sugeng Pujileksono: 151-152)

\section{DISCUSSION}

The number of household heads who live in Pasar 6 Environment I Tanjungsari Subdistrict, Medan Selayang District, is approximately 600 heads of households, while those registered in the General Election are around 300 families or 2,500 people, consisting of various ethnicities in which Javanese are majority and the other is Batak ethnic there are ethnic 
Sundanese, Aceh and Malay, while the majority of the population convert to Islam. Regarding everyday language. The Javanese language in that environment is almost evenly used by the native population there until its present generation. The harmonious and peaceful life is the atmosphere in the neighborhood, the social scene is colored by the frenzy of narcotics-free circulation, the internet, the changing of the city landscape due to the widening of the road, home stores, the presence of lodging, boarding houses and business activities. Part of the new building was a semi-permanent home functioning process with a vast page of parent's legacy. Most of the old houses were semi-permanent with large grounds and grounds. They live together with relatives who still have a kinship. The transfer of functions may be due to the division of inheritance to his children and some temporarily or permanently transfers to others of the second generation of society there. From there the model of life there began to look more pragmatic because of economic demands, urban movements, the rate of urbanization job seekers (labor and office), lectures and factors caused by marriage. As a result many immigrants both women and men are relatively young. They have homes and buy land and houses sold by the old people. But the interaction of immigrants does not necessarily affect the kinship system of the old inhabitants and even new citizens are difficult to stick to any long-established relation activity such as interfamily, inter-family, Do not be surprised in Market 6 is there old family system and new family so that family function is different Head of Environment I Endang Wahyudi, 40, who is also a research informant in the field admitted the above information. Endang is the second generation of the old population who live in groups to build a family relationship that is thick enough in the form of arisan or recitation from one alley to the other alleys along Market 6. He served as head of the neighborhood for the late Suratman's legacy, his parents who had previously been the head of the neighborhood for a long time there to replace the late Rashim. He said about 10 or 15 heads of old families (first generation) live spreading in about 10 alleys in the neighborhood that build next-generation family relationships (second and third generation or grandchildren). One of the 15 families has several children (second generation) who produce grandchildren.

One family (first generation) sometimes has 10 children who then form a social relationship by establishing recitation and arisan until the age of 20 years. Arisan is still running. 
So also the young people seduce or relate in the yard of the youth community. There are parental statements that he still remembers as well as glue the relationships between families there until now, namely "know your family and remember who you are" and "we live not alone". In addition there is another phrase "remember the neighbors, remember the family." The statement conveys parents to their children or extended family members, both in the nuclear family and on certain occasions. These statements as a primary responsibility of family members or called family "talking or conversation" include elements of verbal and nonverbal communication. These ways contribute to the development of a strong self-concept for all family members, especially in young children (Yerbi, Buerkel-Rothfuss, \& Bochner, 1995). Even D.H Demo (1987) emphasizes the intention that self-concept is shaped, nurtured, strengthened, and / or altered by communication from family members. Further (Budyatna \& Ganiem: 170) that the self-concept of family members is improved in the following way: 1). Statement of praise: "Yanto, amazing you have played beautiful in the game of basketball competition this afternoon". 2). Welcome and support statement: "Joko, if you have a good reason to cancel your participation in mountain climbing, we can accept your decision". 3). Love statement: "Sonny, I can feel how painful the bad play is in the badminton game before the family, but we are the one to you and will be present in the next game". Verbal and non-verbal statements in a family communication as above are very strategic to encourage the level of action according to what is implied from the message. It was corroborated by John Greene who first published the Theory of Collecting Action part of Interpersonal Communication Theory in 1984.

This theory tries to explain where our thinkers came from and how we translate these thoughts into verbal and nonverbal communication. He argues that people organize and store knowledge about the meaning of something and how to act something and then use that knowledge in action. When people meet a similar situation, they remember, or collect, this memory and design the course of action (Littlejohn \& Foss: 662). Endang feels statements that form concepts or characters are designed to act between family members. He acknowledged the statement as a strong capital forging family resilience and social relations in his environment, especially in the face of challenges and increasingly complicated issues. Endang also admitted to 
not knowing whether the parent's inheritance is valid for the next 10 or 20 years because the indication of family resilience and function is weakened in the family communication aspect as above. "I am pessimistic that the relation between families on the next generation can be continued," he said. Endang gives his view that many parents now in their environment who do not continue the way of family communication in which contribute to the formation of selfconcept or character of child . even though principle of family communication shows that the importance of messages and relationships in interpersonal communication. People have a lot of communication. One communication goal can be achieved through many different messages and one message can meet many different purposes (Littlejohn \& Foss: 661).

Regardless of how the future challenges of the next generation, now the next generation of parents and their relatives (second generation) in Pasar 6 has been functioning to build their interrelationship till now in the form of recitation, wirit and arisan. This is in line with the assertion that most functions concerning the family system are the product of communication within the family (Budyatna and Ganiem: 168). Another informant, 65-year-old Susilo, said the pattern of family communication that raises the term old family and new family in the neighborhood. $\mathrm{He}$ claimed to feel his own warm and supportive of old family relationships because it is inherited by parents in the environment. Figure people who used to be a priest in Nurul Mukminin Mosque in Market 6 is called Lek Silok in the family and society. His daily work as a freelance worker. Her parents left a number of plots of land and houses there. The location of the house and her late parents' heritage is only a few meters from her home now. She married Rasmiati, the second child of 11 siblings of the late Rashim and deceased Hj Mariati. Mekua Lek Silok is one of the old people or can be called the first generation in Pasar 6 which also has a number of plots of land and a large parent house exactly on the edge of Jalan Kenanga Raya. After the death of Rashim grandfather and Mariati grandmother, the house and land were divided for his son. Now her six children (second generation) inhabit the house side by side. The division of land and the main house building is only separated by the brick wall coverings. The house facing the road was formed semi house shop. The children of Rashim grandmother live with their parents' inherited entrepreneurship, in front of the house such as selling breakfast, soup, groceries and some of the 
land and house distribution have changed hands but the buyers are still close relatives of their parents first. While the son of Rasyim grandfather chose as a freelancer. Formerly Rashim grandmother and his wife did not have an adequate level of education as well as most of their children quit primary school. Likewise, Rashim grandfather has been an influential person in the environment because he is a figure who is good at respecting, appreciating, tenacious and easy to build relationships so that appointed head of the environment at the Market 6 Rasyim grandfather and his parents in the community, including Lek Silok and Endang parents, are called old families whose children (second generation) continue to build social relationships in the form of family gatherings and recitals that have been around for 20 years. Back to Lek Silok, he and his family were among those who got the distribution of the house and settled in the row of the house of his father-in-law Rashim grandfather . Furthermore, Lek Silok and his wife invited four of his daughters-in-law to occupy the house part of the division of his parents in Gang Wiria one person lives with him.

They live from the alley to the alley. Thus the old family bases are patterned in kinship that co-exist. Similarly, the family of Rashim grandfather, although the relics of the main house in front of Jalan Kenanga Raya but the location of his house entered the Peace Gang section. So also in the alley there are several plots of land and heritage house. Some have been sold remaining one plot of land and a house that is now occupied the first daughter named Rasmi (second generation) who now has seven grandchildren. Two children of married mother Rasmi lived in the house also helped connect family relationships there by following recitation and arisan. According Lek Silok, the old family is formed from the first generation of parents who first settled the environment, while the new family is an outsider or urban as a job seeker, college, open business, office and others. For that reason there is a rarity or fundamental conflict. All family and social problems are brought in arisan, recitation, mutual forgiveness forgive before entering Ramadan and youth gathering. Mutual visits and greetings, especially on Eid al-Fitr by the parents are still running until now.

The tools of social relations are always there conversations about the news of children, grandchildren, brothers to the current environmental situation. With capital "talking while 
smoking cigarettes" between families will usually find a solution. So also with the problems of misfortune and the wedding can be handled together without putting money forward. Lek Silok said family communication with the statement of love, welcome and support and praise from parents used to contribute to the formation of self concept become the main responsibility that family members have from their parents from the past until now. In addition, family communication and interaction with others with ways of acknowledging and supporting individual relatives.

Besides giving a sense of comfort in the family. Their parents were not preoccupied with their work like the current demands of going home late at night even overtime and away from home, but only entrepreneurship at home and use of energy while entrepreneurship. Under these conditions, family communication always provides the necessary recognition and support from parents to their children.According to Lek Silok, rarely communicating family conflicts or not support each other. The man who has six grandchildren said the public atmosphere here cool, despite the growing economic demands, technological developments to rapid social changes to make the family face increasingly severe challenges. He acknowledges that some of the above demands affect family functions but they can be anticipated by initiative to move a small economy by selling and so forth in front of the house or other place. In addition, the youngster's relationship is well preserved in organizations such as youth or making organization community. This relationship is built not apart from the concept of self-implanted parents through the actions and family communication. In subsequent interviews, Lek Silok said almost the average parent of the old family inherited the entrepreneurial spirit and freelancers. Indirectly the two jobs are transmitted to the child and his son-in-law. The vast home page of parent's legacy is used to trade by making small kiosks in front of the house or building a few plots, while her husband as a freelancer. Thus the question of economic demands that hit at this time not to be too weak in the function of extended family let alone to triggered a fundamental conflict. Old family parents leave a good interpersonal relation as well as good personality, good religion, better physical and mental health, meet each other's good social needs during their inter-age life as well as parents of today's second generation who continue to capitalize the personality of his parents until now. The 
above elements as part of the determinants in the scope of interpersonal communication (Littlejohn \& Foss: 658). The 60-year-old Murniati who is also an informant in this research reinforces that the arisan they built has been 20 years. He is the younger brother of the deceased Hj Mariati, a long-standing survivor who has built an intimate family communication between family members and social relations. Communication between children, parents, and parents can be a source of joy. From an interview with Murniati who is also still an arisan board, it is revealed that Rasyim arrived at the age of 80 and $\mathrm{Hj}$ Mariati was 76 years old, before dying, continued to provide high-level mutual love to his children and grandchildren on an ongoing basis. Williams and Nussbaum (2001) found many factors that explain the strength of parentchild relationships that are 70 years old or older, namely the urgency of parent-the eternal child remains satisfactory if there is a fixed relationship. In addition, despite the elderly, according to Murniati, the two of them and their parents continue to provide social support and real assistance and the agreement on values, beliefs and moral statements that form self-concepts such as "fellow brothers do not mutually jealous "," live in harmony "," do not be stingy "," do not forget to pray "and" wake up the relationship of friendship and visit each other ". While the agreement on values and beliefs that he built in the family mutual mutual cooperation. Not only the statements alone, Rasyim and his wife leave the habit of gathering with fellow children-in-law and grandchildren at his house every time before Ramadan to mutual reciprocation and visit from house to house on Eid al-Fitr. According Murniati, the way the family communication and custom built that continue to be implemented by successors now so that the character builds for future generations to keep mutual respect and care for each other between families The family communication above forms a shared social reality on the importance of building family resilience in the old community in the Neighborhood I Tanjungsari Village, Medan Selayang Sub-district. The family does create a shared reality through two approaches of communication behavior: the conversation and conformity orientation which also determine the pattern of family communication (Berger al: 688-689). The orientation of the conversation was long built in the community of Neighborhood I Tanjungsari Masih Village in Berger, the orientation of the conversation refers to open communication and often between parents and children with the 
purpose of digging together the meaning of symbols and objects that are the social environment of the family. This is related to relationships that are only supportive characterized by mutual respect and concern for one another.

Likewise patterns of communication with the orientation of obedience also awakened in the family communication between parents and children who contribute in building family resilience. Most of the messages of kindness and self-concept came from parents directly among them the importance of visiting each other among the brothers in the neighborhood and sending children to the pesantren. Parents hold the authority to give opinions, responses and actions to social reality (Berger al: 689). mother son, Ridho 35 years old, is still the third generation of old family in san as well as the writer's informant reveal the above information can be felt until now. $\mathrm{He}$ has also been involved with an arisan that is over 20 years old built by grandmothers and grandparents (parents of mother). It is typical of family communications to the old community there who uphold family secrets and restrictions on taboo matters. The message was conveyed by parents to children, especially their families, so the families there maintained unusual topics in family gatherings. At the time of the late Usman AS, the husband of Ibu Rasmi, the first son of the deceased Rashim, was still alive, had told him about his son and son-in-law related to him selling the land and the money he would use for the pilgrimage. After a few months Pak Usman died the information spread among the family but it was still limited that Pak Usman had saved the pilgrimage, and the deceased had hajj through the process of hajj or replacing Hajj through other people but the condition is the person who has ever gone to the holy land. Some familiar families were touched and shocked by the information.

It was delivered the deceased son. "And we do not tell anyone when you are still there, either to your in-laws or to the siblings of your father and mother," Ridho said. Ridho reveals the message of the father at that time, "do not convey this news (save the pilgrimage) to others. This information is only limited to our families who first knew to avoid assumption of all kinds, let alone the money from the sale of ancestral heritage land (Pak Usman's parents) ". According to Ridho, this family communication applies to the successor generation of our parents. The message is to be transmitted to his son, according to Ridho, that for the people the disclosure of 
secrets is considered to reduce the meaning and familiarity of family relationships and family members can use disclosure to assert greater autonomy and independence from the family (Berger et al: 690). According to Vangelisti (1994), family secrets can be distinguished by form (for example, who hides information from whom), topics (whats undisclosed), and functions (what are the secrets of secrecy effects on the family).

The family's secret form there is the whole family (all family members know, but other people and outsiders do not) down to personal secrets (only one family member knows, but other members of the family and outsiders do not), rule violations (eg, use alcohol, an unmarried pregnancy of one family member) to taboos (eg marital complications, physical and sexual abuse). According to Ridho, the secret function is basically believed the family is positive for family relationships. Vangesti (1994) said the positive thing is related to binding, evaluation, maintenance, privacy, defense and communication. Patterns of family communication built on the basis of interpersonal communication to the old family in Pasar 6 / Environment I Tanjungsari Sub-District Medan Selayang District keeps families in the community performing their functions and has strong resilience with a number of family processes such as conflict resolution (Koerner \& Fitzpatrick, 1997) strengthening and affection (Schrodt, Ledbetter, \& Ohrt, 2007), family rituals (Baxter \& Clark 1996) and mutual understanding (Sillars, Koerner, \& Fitzpatrick, 2005), in addition to child-related outcomes such as communication anxiety ( Elwood \& Schrader, 1998), keuleten (Fitzpatrick \& Koerner, 2005) and mental and physical health of children (Schrodt \& Ledbetter, 2007).

\section{CONCLUSION}

Interpersonal communication plays an important role in forming family resilience and strengthen the function of the family in shaping the character of the young generation of the nation in the midst of an increasingly heavy family challenges as happened to the old family in Pasar 6 Neighborhood I Tanjung sari Village Medan Selayang Sub-district whose parents inherited the family communication capital form self-concepts in children (second and third 
generation) through statements such as "Know your family and remember who you are", "we live not alone" and "remember the neighbors, remember the family." There are positive family relationships and actions built on the basis of conversation, conformity, dependency and distribution of power that comes from parents and children as in the family in Pasar 6 Environment I Tanjungsari Village, Kec. Medan Selayang, thus building a warm and supportive relationship that is characterized by mutual respect and care for each other. With the capital of interpersonal communication, the family can function in building relationships between families and social relations for 20 years such as social gathering and recitation of day or night. filled religious tausiyah by an ustadz. The meeting as a means to instill the nature of patience, solemnity, a sense of reverence for the blessings given the Almighty to one of the family. In addition to praying for the parents and families affected by disasters such as sickness or death. Family communication to old family in Pasar 6 Environment I Tanjungsari Subdistrict Medan Selayang District upholds family secrets and restrictions on taboo matters. The message was conveyed by parents to children, especially their families, so the families there maintained unusual topics in family gatherings. Such attitudes are believed to be binding, evaluation, maintenance, privacy, defense and inter-family communication.

\section{REFERENCES}

Berger, C.R., Roloff, M.E \& Ewoldsen, D.R.R (2011).Handbook Communication Science. USA: Wadswoth.

Budyatna, M dan Ganiem, L.M (2011).Teori Komunikasi AntarPribadi, Jakarta: Prenada Kencana.

Baxter, L.A., \& Clark, C.L. (1996). Perceptionss of family communication patterns and the enactment of family rituals. Western Journal of Communications, 60, 254-268.

Demo, D.H, (1987). Family Ralations And The Self-Esteem of Odalescent and Their Parents. Journal of Marriage and Family. Vol. 49.

Elwood, T.D., \& Shrader, D.C.,(1998). Family communication patterns and communication 
apprehesion. Journal of Social Behavior an Personality, 13, 493-502.

Fitzpatrick, M.A., \& Koemer, A.F. (2005). Family communication schemata within schemata: Effect on children's resiliency, In S. Dunwoody, L.Becker, D.McLeod, \& G. Kosicki. (eds.)

Koerner, A.F., \& Fitzpatrick, M.A (1997). Family type and conflict: The impact of conversation orientation and conformity orientation on conflict in the family . Communication Studies, 48, 59-75 Harian Umum KOMPAS (2017) Jakarta

Littlejohn, S.W\& Foss, K. A (2016), Encyclopedia of Communication Theory, AS: Sage Publication Inc.

Sugeng Pujileksono, (2015). Metode Penelitian Komunikasi Kualitatif, Malang: Intrans Publishing.

Schrodt, P., Ledbetter, A.M., \& Ohrt, J.K (2007). Parental confirmation and affection aas mediators of family communication pattern and children's mental well-being. Journal of Family Communication, 7, 23-46.

Sillars, A., Koerner, A.F., \& Fitzpatrick, M.A (2005). Communication and understanding in parent-adolescent relationships. Human Communication Research, 31, 103-128.

Schrodt, P., \& Ledbetter, A.M. (2007). Communication processes that mediate family communication patterns and mental well-being: A mean and covariance structures analysis of young adult from divorced and non-divorced families. Human Communication Research, 33, 330-356

Vangelisti, A.L (1994). Family secrets: Forms, functions and correlaters. Journal of Social and Personal and Personal Relationship, 11, 113-135.

Wiliam, A dan Nussbaum, J.F, (2001). Intergenerational Communication Across The Lifepain. Mahwah, N.J.: Erlbau 